\title{
Assessment of Liquid Waste Handling Practice of Addis Ketema and its Impact on Shankela River, Addis Ababa, Ethiopia
}

\author{
Solomon Tibebu ${ }^{1,2,3 *}$, Abebe Worku ${ }^{1,2}$, Abebaw Shebeshi ${ }^{1,2}$, Estifanos Kassahun ${ }^{2,3,4,5}$
}

\footnotetext{
${ }^{1}$ Environmental Engineering, College of Biological and Chemical Engineering, Addis Ababa Science and Technology University, Addis Ababa, ETHIOPIA

${ }^{2}$ Sustainable Energy Center of Excellence, Addis Ababa Science and Technology University, Addis Ababa, ETHIOPIA

${ }^{3}$ Biotechnology and Bioprocess Center of Excellence, Addis Ababa Science and Technology University, Addis Ababa, ETHIOPIA

${ }^{4}$ Department of Chemical Engineering, College of Biological and Chemical Engineering, Addis Ababa Science and Technology University, Addis Ababa, ETHIOPIA

${ }^{5}$ Ethiopian Food, Beverage, and Pharmaceutical Industries Development Institute, ETHIOPIA

*Corresponding Author: solomon.tibebu@aastu.edu.et
}

Citation: Tibebu, S., Worku, A., Shebeshi, A. and Kassahun, E. (2022). Assessment of Liquid Waste Handling Practice of Addis Ketema and its Impact on Shankela River, Addis Ababa, Ethiopia. European Journal of Environment and Public Health, 6(1), em0097. https://doi.org/10.21601/ejeph/11500

ARTICLE INFO

Received: 1 Sep. 2021

Accepted: 24 Oct. 2021

\begin{abstract}
Addis Ketema is one of the ten sub-cities of Addis Ababa, where the biggest market and the biggest bus station in Ethiopia are located. The liquid waste that is generated from this sub-city is not being handled properly. The objective of this study is to assess the liquid waste handling practice of Addis Ketema and its impact on Shankela River. The data is collected by observation, interviewing garage employees, and interviewing residents. In addition, a triplicate water sample was collected from four sampling sites of Shankela River by using grab sampling. The physicochemical characteristics of the river such as temperature, $\mathrm{pH}$, electric conductivity, dissolved oxygen, total suspended solids, total dissolved solids, biological oxygen demand, and chemical oxygen demand were analyzed to determine the impact of the poor liquid waste handling practice of the sub-city on the river. The main reasons that contributed to the poor liquid waste handling practice of Addis Ketema are the discharge of untreated effluents from small and large scale factories, the migration of people from different parts of the country, the poor liquid waste handling practice of residents, the poor solid waste handling practice of Merkato and Autobis Tera, the poor liquid waste handling practice of condominium's and the poor liquid waste handling practice of garages. The interview result shows that out of 81garage employees, only 43 percent have a perception about the health and environmental impacts that come with the poor handling of garage effluent. The questioners that are collected from residents show that compared to other zones, zone 3 has poor liquid waste handling practice. Zone 3 is the third zone with 61 out of 100 residents in having low perception about environmental pollution. It is the first zone in having large number of residents, with 87 out of 100 residents, to be affected with water-borne diseases. It is the third zone with 62 out of 100 residents in dumping their liquid waste improperly. It is the last zone with 12 out of 100 residents in handling the generated liquid waste properly and it is the second zone with 45 out of 100 residents in using bottled water over the water that is supplied by Addis Ababa water and sewerage authority. The physicochemical characteristics of Shankela River indicate that even though the river is polluted by other factors before entering into the sub-city, the poor liquid waste handling practice of the sub-city is affecting the river even more by increasing the pollutant load. Developing sanitary infrastructures, Awareness creation, enforcing environmental laws are some of the methods that can be employed to improve the poor liquid waste handling practice of Addis Ketema.
\end{abstract}

Keywords: drainage channel, liquid waste handling, sanitary facility, sub-city, waterborne diseases

\section{INTRODUCTION}

Water is one of the main necessities to live on planet earth (Gbadegesin and Akintola, 2020; Goncharuk, 2013; Ukpaka and Ukpaka, 2016). Water is used for different purposes such as domestic, industrial, and agricultural activities (Berhe, 2020). After the water is used for different activities, it will be changed into wastewater. According to Amoatey and Bani (2011), wastewater is water, whose physical, chemical, and biological property is changed due to the introduction of certain substances. Domestic wastewater in general, grey and black water in particular generates a large amount of wastewater in cities (Oladoja, 2017). Industrial effluents are also increasingly contaminating the environment from time to time (Iqbal et al., 2019). According to Palaniappan et al. (2010), industrial sectors are also responsible for dumping 300-400 million tons of heavy metals, solvents, toxic sludge, and other wastes into water bodies each year. 
According to Abebaw (2017) and Manderso (2018), 80-90 percent of the world's wastewater is discharged directly into the environment without treatment. This indicates that many countries around the world are not managing their wastewater properly. This might be resulted due to the poor development of sanitation facilities. According to van Dijk et al. (2013), about 2.6 billion people have no access to improved sanitation. Due to this, different environmental media such as water and soil are being affected by contaminants (Pirastu et al., 2013). Even though the liquid waste handling facilities are increasing substantially in developed countries, the situation is different in developing countries (Manderso, 2018).

More than half the population in developing countries does not have access to sanitation (Mekonnen, 2012). In most developing countries, lack of sanitation infrastructure has been the main reason for the poor liquid waste handling practice (Bosch et al., 2001; Joshi and Amadi, 2013). According to Manderso (2018), only 32 percent of developing countries have access to sanitation services. This problem is aggravated by rapid population growth, urbanization, and industrialization (Liyanage and Yamada, 2017, Musoke et al., 2018). Due to this, the planning and expansion of sanitary infrastructures in most African countries are very difficult (Loucks and van Beek, 2017). Many governments of African country do not give attention to wastewater collection and handling facilities because they are dealing with war, conflict and food security (Haddis et al., 2014). Moreover, the habit of open field disposal is another big problem in developing countries (Shrestha, 1988).

Almost all of the sewerage systems and wastewater treatment plants in Ethiopia are poorly managed (Haddis et al., 2014). The coverage of sanitation facilities in the country is very low (Admassu et al., 2004). About half of the households in Ethiopia openly discharge grey water into public properties such as drainage lines, streets, and nearby open spaces, and only 4.5 percent of Ethiopians have access to flush and pit latrines (Manderso, 2018).

The 2007 senses indicate that over three million people live in Addis Ababa (CSA, 2012). This population is expected to rise to 7.5 million in 2030. However, the development of sanitation infrastructure in Addis Ababa is very slow. This city has two main sewage treatment plants. The first plant, which is called the Kality treatment plant, treats around $7600 \mathrm{~m}^{3} / \mathrm{d}$. The second treatment plant is called the Kotebe treatment plant. This plant only treats sludge from septic tanks that are transported by vacuum tracks (Van Rooijen and Taddesse, 2009). In Addis Ababa, the liquid waste that is generated from industries, institutions, and residents is not being handled properly. Moreover, the overflow of stormwater into the streets especially during the rainy season poses additional sanitation problems (McFarland et al., 2019).

If the generated liquid waste is not managed properly, it will harm the health of both humans and the environment (Bienfang et al., 2011; Gbadegesin and Akintola, 2020; Jensen et al., 2018). Wastewater typically contains disease-causing agents, oxygen demanding waste, water-soluble inorganic chemicals, inorganic nutrients, organic chemicals, sediments, radioactive waste, etc. (Amin et al., 2014). Around 842,000 people die every year worldwide due to water-born diseases (Chalchisa et al., 2018). Unsanitary environments are favorable for the outbreak and spread of different communicable diseases (Exum et al., 2019; Kayiwa et al., 2020; Mekonnen, 2012). Typhoid, trachoma, guinea worm, malaria, Cryptosporidium parvum, and sleeping sickness are some of the diseases that result from contaminated water (Busvine, 1993; Li et al., 2019). Eutrophication, which is caused by the presence of excessive nutrient in water bodies, affect the aquatic ecosystem by covering the surface of the water body by algae, decreasing dissolved oxygen, altering the penetration of light into water bodies and creating a bad odor (Dorgham, 2014). The industrial effluents that contain different heavy metals such as chromium, silver, nickel, copper, arsenic, and lead are increasingly affecting the environment from time to time (Bazrafshan et al., 2015; Noreen et al., 2017). According to $\mathrm{Wu}$ et al. (2016), heavy metals have carcinogenic, mutagenic, and teratogenic behavior. Liver damage, lung damage, kidney damage, gastric damage, vomiting, pulmonary congestion, and diarrhea are some of the health effects that are caused by heavy metals (Jaishankar et al., 2014). The wastes from garages such as used oil, paint, lubricants, cleaning solvent, used batteries and petroleum products are also causing a significant problem by contaminating water bodies (Fayiga et al., 2018). Therefore, managing wastewater is very crucial for living in a clean and healthy environment. Handling and treatment of wastewater are important steps in wastewater management. According to Parween and Ramanathan (2019), wastewater management is a systematic administration activity that provides proper collection, handling, treatment, and disposal of wastewater in an environmentally friendly way.

Out of ten sub-cities, Addis Ketema is one of the sub-city of Addis Ababa. The biggest market in Ethiopia, Merkato is located in this sub-city. The biggest bus station in the country, Autobis Tera is also located in this sub-city. Due to these two main reasons, a large population can be found in this sub-city. This sub-city has a big problem in handling both solid and liquid wastes. The blockage of open drainage channels by solid waste, the entry of sewage into water supply pipes through leaky joints, the poor solid and liquid waste handling practices of residents, industries, and garages, are some of the problems that can be observed in Addis Ketema. These problems need to be scientifically studied and mitigated for improving the quality of liquid waste handling practice of Addis Ketema and minimizing the pollution of Shankela River.

Some researchers researched the liquid waste handling practice of the different parts of the country, Ethiopia (Alemayehu et al., 2020; Amare et al., 2017; Beyene et al., 2015; Haddis et al., 2014; Manderso, 2018; Van Rooijen and Taddesse, 2009). However, as far as the knowledge of the authors is concerned, no research has been conducted on the sub-city of Addis Ketema. Therefore, this study aims to assess the liquid waste handling practice of Addis Ketema by collecting data using interviews, questioner, and observation. This study also aims to assess the impact of the poor liquid waste handling practice of Addis Ketema on Shankela River by characterizing the river at different sampling points. 


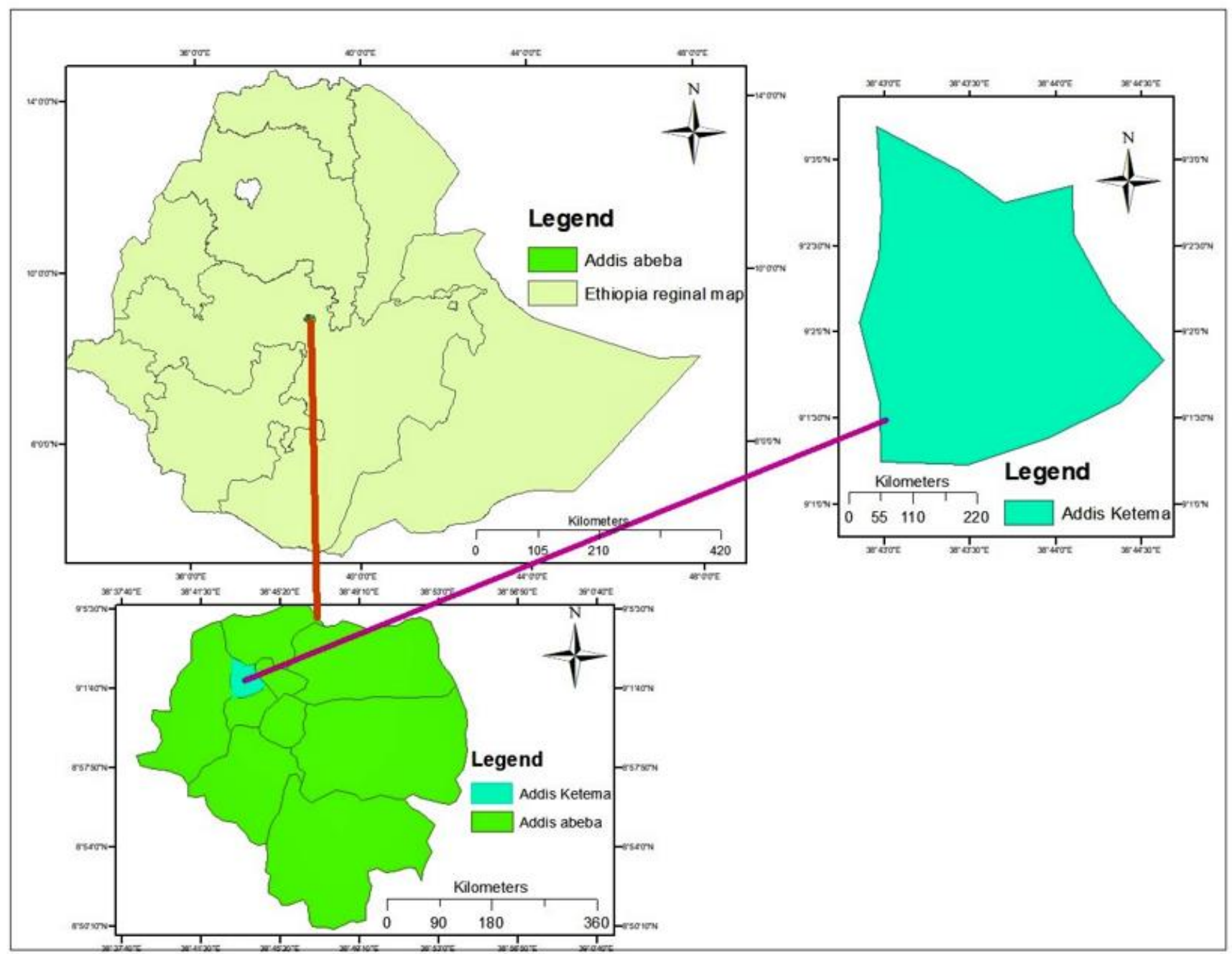

Figure 1. Study area

\section{MATERIALS AND METHODS}

\section{Study Area}

Addis Ketema is located at 9002'59” N and 38 $43^{\circ}$ '54" E and has an altitude of $2459 \mathrm{~m}$. It has an average temperature, rainfall, and relative humidity of $15.9 \mathrm{C}^{0}, 1,089 \mathrm{~mm}$, and 60.7 $\%$, respectively. As of 2011, this sub-city has a total population of 271,644. Addis Ketema sub-city has ten administration zones and covers a total area of $7.41 \mathrm{Km}^{2}$. Different schools, hospitals, theater halls, churches, mosques, the largest market in the country, the largest bus station in the country, and small and large scale industries are located in Addis Ketema. Figure 1 shows the study area, which is Addis ketema sub-city.

\section{Data Collection and Analysis}

The data was collected by observation, interviewing the officers of both Addis Ababa environmental protection authority (AAEPA) and Addis Ketema environmental protection authority (AKEPA), and interviewing some employees that work in garages. There are 42 garages and 435 garage employees in Addis Ketema. The garage employee's perceptions of the health and environmental impact that comes with the poor liquid waste handling practices of the garage were assessed. Data is also collected by questionnaires from residents. The participants, who filled the questionnaires, were randomly selected. The questioner data was collected by four BSc students. The participants were informed and assured that the survey is purely for academic purposes. The sample size of the garage employee's interview and residents' questionnaires is determined using Slovin's formula as follows (Slovin, 1960):

$$
n=\frac{N}{\left(1+N e^{2}\right)}
$$

where $\mathrm{n}$ is the sample size for the infinitive population, $\mathrm{N}$ is the population size and $\mathrm{e}$ is margin of error $(\mathrm{e}=0.1)$.

The sample size of the interview (garage employees) was 81. The sample size of the questioner (residents) was 1,000 . The status of the residents, who filled the questionnaire is presented in Table 1.

The data that was obtained from the questionnaire is organized into five main categories. These are (1) the number of residents that have a perception about environmental pollution, (2) the number of residents that have been affected with water-borne diseases, (3) the number of residents that dump their solid waste improperly such us in drainage channels, (4) the number of residents that handle the generated liquid waste properly such as discharging their 
Table 1. Status of the participants who participated in filling the questionnaire

\begin{tabular}{|c|c|c|c|c|c|c|}
\hline \multirow{2}{*}{ No } & \multirow{2}{*}{ Zone } & \multirow{2}{*}{$\begin{array}{l}\text { No. of participants } \\
\text { (Sample size) }\end{array}$} & \multicolumn{2}{|c|}{ Age } & \multicolumn{2}{|c|}{ Educational status } \\
\hline & & & Range & No. & Range & No. \\
\hline \multirow{5}{*}{1} & \multirow{5}{*}{ Zone 1} & \multirow{5}{*}{100} & $12-18$ & 41 & Illiterate & 32 \\
\hline & & & $19-45$ & 36 & Elementary School & 2 \\
\hline & & & $46-50$ & 18 & High School & 29 \\
\hline & & & $51-80$ & 4 & BSc & 34 \\
\hline & & & $81<$ & 1 & MSc and above & 3 \\
\hline \multirow{5}{*}{2} & \multirow{5}{*}{ Zone 2} & \multirow{5}{*}{100} & $12-18$ & 21 & Illiterate & 54 \\
\hline & & & $19-45$ & 32 & Elementary School & 8 \\
\hline & & & $46-50$ & 28 & High School & 11 \\
\hline & & & $51-80$ & 13 & BSc & 23 \\
\hline & & & $81<$ & 6 & MSc and above & 4 \\
\hline \multirow{5}{*}{3} & \multirow{5}{*}{ Zone 3} & \multirow{5}{*}{100} & $12-18$ & 11 & Illiterate & 65 \\
\hline & & & $19-45$ & 31 & Elementary School & 2 \\
\hline & & & $46-50$ & 33 & High School & 6 \\
\hline & & & $51-80$ & 19 & BSc & 26 \\
\hline & & & $81<$ & 6 & MSc and above & 1 \\
\hline \multirow{5}{*}{4} & \multirow{5}{*}{ Zone 4} & \multirow{5}{*}{100} & $12-18$ & 26 & Illiterate & 46 \\
\hline & & & $19-45$ & 34 & Elementary School & 5 \\
\hline & & & $46-50$ & 15 & High School & 18 \\
\hline & & & $51-80$ & 17 & BSc & 31 \\
\hline & & & $81<$ & 8 & MSc and above & 0 \\
\hline \multirow{5}{*}{5} & \multirow{5}{*}{ Zone 5} & \multirow{5}{*}{100} & $12-18$ & 34 & Illiterate & 29 \\
\hline & & & $19-45$ & 18 & Elementary School & 5 \\
\hline & & & $46-50$ & 28 & High School & 27 \\
\hline & & & $51-80$ & 17 & BSc & 36 \\
\hline & & & $81<$ & 3 & MSc and above & 3 \\
\hline & & & $12-18$ & 23 & Illiterate & 51 \\
\hline & & & $19-45$ & 32 & Elementary School & 1 \\
\hline 6 & Zone 6 & 100 & $46-50$ & 31 & High School & 19 \\
\hline & & & $51-80$ & 12 & BSc & 27 \\
\hline & & & $81<$ & 2 & MSc and above & 2 \\
\hline & & & $12-18$ & 29 & Illiterate & 49 \\
\hline & & & $19-45$ & 32 & Elementary School & 4 \\
\hline 7 & Zone 7 & 100 & $46-50$ & 11 & High School & 23 \\
\hline & & & $51-80$ & 26 & BSc & 24 \\
\hline & & & $81<$ & 12 & MSc and above & 0 \\
\hline & & & $12-18$ & 36 & Illiterate & 44 \\
\hline & & & $19-45$ & 26 & Elementary School & 7 \\
\hline 8 & Zone 8 & 100 & $46-50$ & 21 & High School & 27 \\
\hline & & & $51-80$ & 13 & BSc & 22 \\
\hline & & & $81<$ & 4 & MSc and above & 0 \\
\hline & & & $12-18$ & 31 & Illiterate & 49 \\
\hline & & & $19-45$ & 26 & Elementary School & 4 \\
\hline 9 & Zone 9 & 100 & $46-50$ & 36 & High School & 18 \\
\hline & & & $51-80$ & 5 & BSc & 29 \\
\hline & & & $81<$ & 2 & MSc and above & 0 \\
\hline & & & $12-18$ & 36 & Illiterate & 48 \\
\hline & & & $19-45$ & 28 & Elementary School & 7 \\
\hline 10 & Zone 10 & 100 & $46-50$ & 24 & High School & 17 \\
\hline & & & $51-80$ & 11 & BSc & 26 \\
\hline & & & $81<$ & 1 & MSc and above & 2 \\
\hline
\end{tabular}

wastewater in septic tanks, and (5) the number of residents that purchase bottled water for drinking purpose.

It is important to evaluate the resident's perception of environmental pollution. When a large number of residents have a perception of environmental pollution, a large number of residents will handle their liquid waste appropriately. The number of residents that have been affected by water-borne diseases can be one indicator of poor liquid waste handling practices. This has a direct relationship with the way how the residents handle their liquid waste. If a large number of residents have been affected, there might be a problem related to how residents handle their liquid waste. The number of residents that dump their solid waste properly and the number of residents that handle their liquid waste properly was assessed and the generated data was supported by observation, interviewing AAEPA officials, and AKEPA officials. The number of residents that purchase bottled water for drinking purposes can indicate whether the water that is supplied by Addis Ababa Water and Sewerage Authority (AAWSA) is safe 


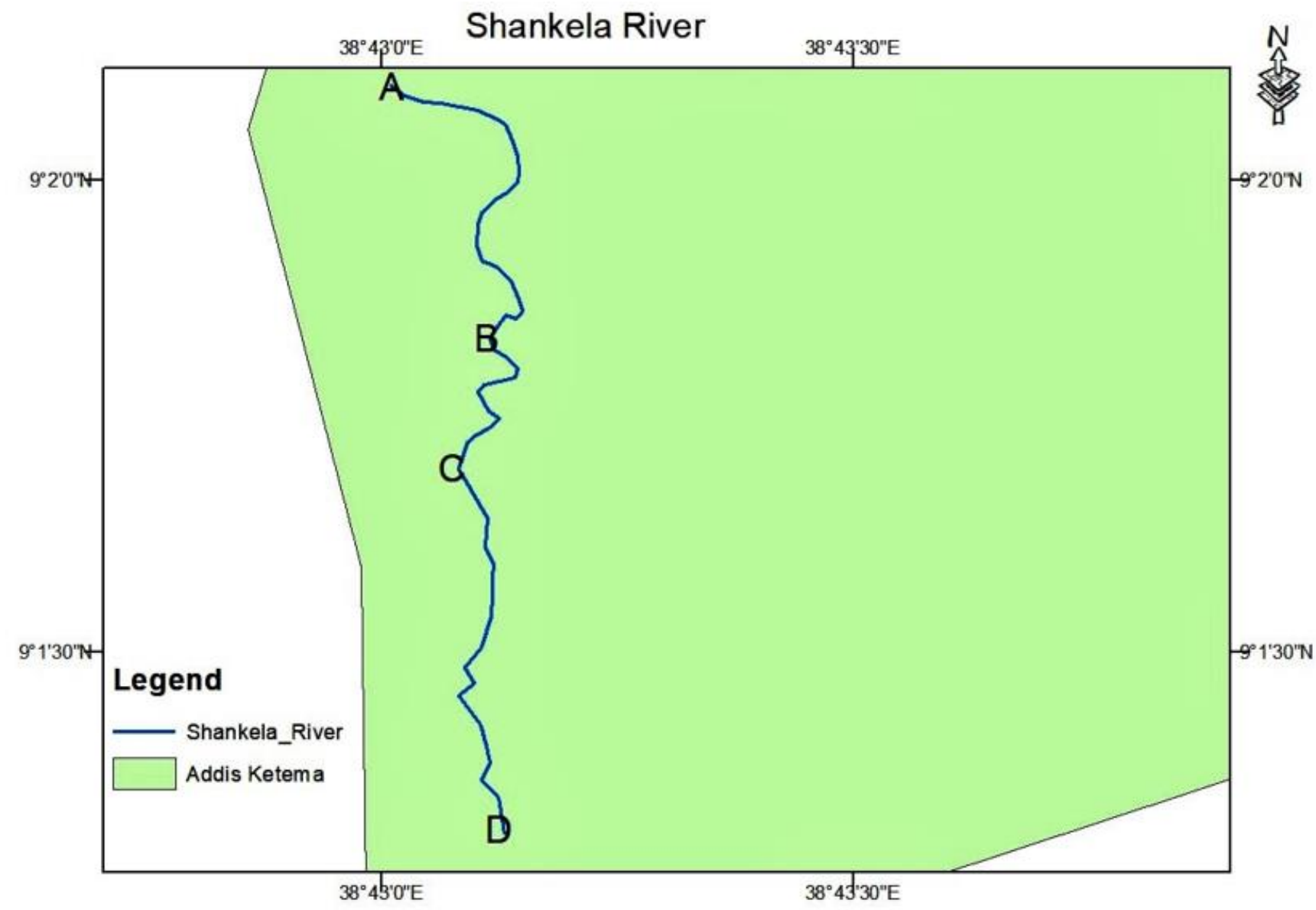

Figure 2. Sampling points in Shankela River

for drinking. If there is poor liquid waste handling practice in one area, the probability of contamination of the water supply system is very high. However, drinking bottled water might be related to the economic background of the residents that live around that area. To consider this factor, the data is supported by observation.

A triplicate water sample was also collected from four locations of Shankela River by using grab sampling to determine the impact of the poor liquid waste handling practice of the sub-city on the river as shown in Figure 2. The generated data was averaged and the standard devation was analyzed using Microsoft Excel 2013. The river is flowing from point A to the direction of point $\mathrm{D}$.

The sampling site was selected by considering the active sites, where different pollutants from small-scale and largescale factories, garages, sewerage channels, and toilet effluents join the river. The first and fourth sampling points were selected at the point where the river enters and exits the sub-city respectively. Table 2 shows the geographical coordinates of the four sampling sites.

Table 2. Geographical coordinate of sampling points

\begin{tabular}{ccccc}
\hline \multirow{2}{*}{ No. } & Sampling & \multicolumn{3}{c}{ Coordinate } \\
\cline { 3 - 5 } & Point & $\mathbf{X}$ & $\mathbf{Y}$ & $\mathbf{Z}$ \\
\hline 1 & $\mathrm{~A}$ & 9.035003 & 38.71680 & 2403 \\
\hline 2 & $\mathrm{~B}$ & 9.030575 & 38.71857 & 2392 \\
\hline 3 & $\mathrm{C}$ & 9.028808 & 38.71820 & 2388 \\
\hline 4 & $\mathrm{D}$ & 9.022081 & 38.71876 & 2386 \\
\hline
\end{tabular}

The temperature, $\mathrm{pH}$, electric conductivity (EC), and dissolved oxygen (DO) were measured on-site using portable instruments. The temperature and $\mathrm{pH}$ were measured using a portable $\mathrm{pH} /$ temperature meter (Model HANA 83141). The DO and EC were measured using a portable DO meter (Model WTW Oxi 3310 SET 1) and portable EC meter (Model HANA HI 8733) respectively. Total suspended solids (TSS) and total dissolved solids (TDS) were analyzed by the gravimetric method. Biological oxygen demand $\left(\mathrm{BOD}_{5}\right)$ was analyzed by 5210 respirometric monometric method and chemical oxygen demand (COD) was analyzed by 5220 colorimetric methods using a spectrophotometer (Model Hath DR3900). All wastewater parameters were analyzed according to Rice et al. (2012).

\section{RESULTS AND DISCUSSION}

\section{Liquid Waste Handling Practice of Addis Ketema}

According to the data, which is collected by observation and interviewing the officers of both AAEPA and AKEPA, it can be said that six main reasons contributed for the poor liquid waste handling practice of Addis Ketema. These are;

- the discharge of untreated effluents from small and large-scale factories,

- the migration of people from different parts of the country, 
- the poor liquid waste handling practices of residents,

- the poor solid waste handling practices of Merkato and Autobis Tera,

- the poor liquid waste handling practice of the condominium houses, and

- the poor liquid waste handling practice of garages.

There are around 72 small-scale factories (27 textile factories, 22 metal finishing factories, and 23 shoe factories) in this sub-city. These factories discharge their effluent directly into the open drainage channels that were originally designed to transport stormwater. Since these factories are unregistered by the government and located in small villages along with poorly constructed residential homes, they are not being inspected by both AAEPA and AKEPA. In addition to the factories' employees, the residents that live near these factories are exposed to different chemicals. The heavy metals that are found in the effluents have the potential to cause adverse environmental and health impacts (Williams, 2004). There are also around 12 large-scale factories, which include candle factory, plastic factory, metal finishing factory, tannery factory, and textile factory. The effluents especially from tannery and textile factories discharge their untreated effluent directly to the nearby river. Even though AKEPA is trying to stop this pollution by creating awareness and enforcing the environmental law, they are not being successful in stopping these factories from contaminating the environment.

A large amount of the population is migrating from different parts of the country to Addis Ababa to find a better job, earn a good salary and have a better life. The two main reasons for these large amounts of migration especially to this sub-city are the presence of Merkato, the largest market in the country, and Autobis Tera, the largest bus station in the country, in Addis Ketema. Most of the migrants that come from the rural part of the country have little or no perception about the health and environmental impact resulted from the poor handling of solid and liquid wastes. Some residents throw their solid waste on the street and open drainage channels, which leads to the overflow of sewage into the street and resident's homes. This makes the liquid waste handling system very difficult and unsanitary (Gbadegesin and Akintola, 2020). According to Nalwanga and Ssempebwa (2011), poor drainage system causes many environmental and public health problems. This problem becomes worse during Ethiopian rainy seasons (June, July, August, and September). Migration is also one of the reasons for the increment of homeless people in the city, which in turn have a negative impact on the liquid waste handling process. Migrants and homeless people are not the only contributors for the poor liquid waste handling practice. Some residents of Addis Ketema are also responsible for throwing their solid waste on the street and open drainage channels. They also discharge their grey and black water into drainage channels.

The poor solid waste handling practice of the sub-city also plays a big role in the poor liquid waste handling practice. Each day, a large amount of solid waste is generating from residents, industries, Merkato and Autobis Tera. Since the generated solid waste is not being managed properly, it is affecting the liquid waste handling process. The poor solid waste handling process leads to the contamination of soil, surface water, and
Table 3. Summary of the data that is collected by the questionnaire

\begin{tabular}{cccccc}
\hline \multirow{2}{*}{ Zone } & \multicolumn{5}{c}{ Question } \\
\cline { 2 - 6 } & $\mathbf{1}$ & $\mathbf{2}$ & $\mathbf{3}$ & $\mathbf{4}$ & $\mathbf{5}$ \\
\hline 1 & 89 & 69 & 34 & 26 & 26 \\
\hline 2 & 83 & 71 & 44 & 31 & 35 \\
\hline 3 & 61 & 87 & 62 & 12 & 45 \\
\hline 4 & 88 & 62 & 48 & 24 & 35 \\
\hline 5 & 79 & 73 & 54 & 36 & 39 \\
\hline 6 & 78 & 61 & 57 & 27 & 29 \\
\hline 7 & 84 & 64 & 42 & 28 & 27 \\
\hline 8 & 86 & 76 & 37 & 21 & 36 \\
\hline 9 & 75 & 65 & 42 & 18 & 34 \\
\hline 10 & 76 & 64 & 36 & 24 & 23 \\
\hline Average & 79.9 & 69.2 & 45.6 & 24.7 & 32.9 \\
\hline & & & & &
\end{tabular}

groundwater (Deeba et al., 2019; Majolagbe et al., 2016, 2017; Mukama et al., 2016).

The poor liquid waste handling practice of the condominium houses is also causing adverse impacts. These condominiums use septic tanks as a low-cost treatment plant. However, these septic tanks are not being emptied periodically. A good example of this is the septic tank, which is located in zone 3. Due to this reason, sewage is overflowing from the septic tank into residents' homes.

All garages in Addis Ketema discharge their untreated effluent directly into open drainage channels. The garage effluent contains used oil, which is generated from maintenance and car body repair shops. According to ElGawad (2014), used oil can reduce the treatment efficiency of wastewater treatment plants and causes fire hazards if not managed properly.

The interview result shows that out of 81garage employees, 43 percent have a perception of the health and environmental impacts that come with the poor handling of garage effluent. However, the rest of the employees, which is 57 percent, does not have a perception about this. They think that discharging garage effluent such as used oil into open drainage channels is the proper way of disposing of the effluent.

The questionnaire data that is collected from 1,000 residents over 10 zones of Addis Ketema are summarized in Table 3. Out of 100, more than 80 residents have a perception of environmental pollution in zone $1,2,4,7$, and 8 . In zone 5, 6 , 9, and 10 , more than 70 residents have a perception of environmental pollution, but in zone 3 , only 61 residents have perception. On average, around 80 percent of residents have a perception, which indicates that lack of awareness might not be the main reason for the poor liquid waste handling practice of Addis Ketema. However, residents in zone 3 have the lowest perception compared to other zones therefore, AKEPA should work on awareness creation in this zone.

One of the impacts of the poor liquid waste handling practice is its impact on human health. In zone 3, 85 out of 100 residents have been affected by water-borne diseases. In zone 2,5 , and 8 , more than 70 residents and in zone $1,4,6,7,9$, and 10 , more than 60 residents have been affected. On average, around 70 percent of the residents have been affected. This is a very high number. The main reason for this might be due to the entry of sewage into water supply pipes through leaky joints (Attia et al., 2010). 
Table 4. Physicochemical characteristics of Shankela River

\begin{tabular}{|c|c|c|c|c|c|c|}
\hline \multirow{3}{*}{ No. } & \multirow{3}{*}{ Parameters } & \multicolumn{4}{|c|}{ Sampling sites } & \multirow{3}{*}{$\begin{array}{l}\text { Ethiopian } \\
\text { standard }\end{array}$} \\
\hline & & A & B & $\mathrm{C}$ & D & \\
\hline & & $\operatorname{Avg} \pm$ SD $^{*}$ & $\operatorname{Avg} \pm$ SD $^{*}$ & Avg \pm SD $^{*}$ & Avg \pm SD $^{*}$ & \\
\hline 1 & Temperature $\left(\mathrm{C}^{0}\right)$ & $21.7 \pm 1.32$ & $23.1 \pm 2.22$ & $24.8 \pm 2.04$ & $23.5 \pm 2.29$ & $<25$ \\
\hline 2 & $\mathrm{pH}$ & $6.7 \pm 0.31$ & $8.1 \pm 0.86$ & $7.1 \pm 0.90$ & $7.7 \pm 0.60$ & $6.5-8.5$ \\
\hline 3 & $\mathrm{EC}(\mathrm{ms} / \mathrm{cm})$ & $1045 \pm 8.39$ & $1235 \pm 7.60$ & $1263 \pm 8.16$ & $1275 \pm 9.84$ & $<800$ \\
\hline 4 & DO (mg/l) & $4.36 \pm 0.97$ & $3.20 \pm 0.33$ & $2.78 \pm 0.88$ & $1.96 \pm 0.76$ & $>8.5$ \\
\hline 5 & TSS (mg/l) & $118 \pm 10.88$ & $123 \pm 16.54$ & $141 \pm 13.26$ & $158 \pm 11.53$ & $<50$ \\
\hline 6 & TDS (mg/l) & $368 \pm 13.88$ & $513 \pm 25.27$ & $737 \pm 38.53$ & $850 \pm 26.85$ & $<450$ \\
\hline 7 & $\mathrm{BOD}_{5}(\mathrm{mg} / \mathrm{l})$ & $25 \pm 2.07$ & $34 \pm 5.83$ & $48 \pm 8.37$ & $51 \pm 7.00$ & $<5$ \\
\hline 8 & $\mathrm{COD}(\mathrm{mg} / \mathrm{l})$ & $47 \pm 23.74$ & $53 \pm 17.37$ & $64 \pm 11.98$ & $68 \pm 15.28$ & $<20$ \\
\hline
\end{tabular}

*-Standard deviation

In zone 3, 62 out of 100 residents dump their solid waste improperly such as in drainage channels. Since Shankela River mainly flows along zone 3 , most of the solid waste is dumped on this river and this was observed during field visits. More than 50 residents dump their solid waste improperly in zone 5 and 6 . More than 40 and more than 30 residents improperly dump their solid waste in zone $2,4,7$, and 9 and in zone 1,8 , and 10 , respectively. On average 45.6 percent of the residents dump their solid waste improperly.

Out of 100 residents, more than 30 handle their liquid waste appropriately in zone 2 and 5 . In zone 1, 4, 6, 7, 8, and 10 , more than 20 residents appropriately handle their liquid waste. In zone 9 and 3, only 18 and 12 residents appropriately handle their liquid waste respectively. On average, only 24.7 percent of residents appropriately handle their liquid waste. This is a small number, which indicates that most residents handle their liquid waste improperly such as discharging untreated wastewater on the street, on open drainage channels, and on a river. Poorly handled liquid waste can cause a serious impact on both environment and health (Kijanga, 2019).

In zone 3 , out of 100 residents, more than 40 buy and use bottled water for drinking purposes than using the water that is supplied by the city's water and sewerage authority. This is a relatively higher number of residents than the other zones. In this zone, a large number of residents have been affected by water-borne diseases. To prevent water-borne diseases that are caused by poor liquid waste handling practice, residents that have the economic strength buys bottled water while others boil water before drinking. More than 30 residents buy bottled water in zone $2,4,5,8$, and 9 . In zone $1,6,7$, and 10 , more than 20 residents buy water. On average, only 32.9 percent of residents buy and use bottled water to drink.

\section{The Impact of Poor Liquid Waste Handling Practice on Shankela River}

Most of the effluent in the open drainage channels of Addis Ketema flows directly in to a river, which is commonly called the Shankela River (Tarekegn and Truye, 2018). As mentioned earlier, small-scale industries and garages discharge their effluent directly into the open drainage channels. This river is also contaminated by the solid waste that is dumped by the residents and the effluents from large-scale factories, which are located in this sub-city. Some of the toilets, which are constructed by the sub-city's sanitation department for the residents, are connected with this river by pipes. This allows the sewage from the toilet to be disposed of directly into the river without treatment. The physicochemical characteristics of Shankela River that are determined by taking samples from four active sites have been averaged and presented in Table 4.

As shown in Table 4, the EC, TSS, TDS, $\mathrm{BOD}_{5}$, and COD of all sampling points are above the permissible limit and the DO level in all sampling points is lower than the minimum amount of DO that should be present in the river. Compared to sampling point $\mathrm{A}$, which represents the sampling point as the river enters into the sub-city, the EC, TSS, TDS, $\mathrm{BOD}_{5}$, and COD load of the river increased in sampling points $B, C$, and $D$. This indicates that even though the characteristics of the river at sampling point A is above the standard, the poor liquid waste handling practice of the sub-city is affecting the river even more by increasing the pollutant load. Compared to sampling point $\mathrm{A}$, the $\mathrm{EC}$, TSS, TDS, $\mathrm{BOD}_{5}$, and COD of the river are increased by $230 \mathrm{~ms} / \mathrm{cm}, 40 \mathrm{mg} / 1,482 \mathrm{mg} / 1,26 \mathrm{mg} / 1,21 \mathrm{mg} / \mathrm{l}$ at sampling point $\mathrm{D}$. Also, compared to sampling point $\mathrm{A}$, the $\mathrm{DO}$ of the river is decreased by $2.4 \mathrm{mg} / \mathrm{l}$ at sampling point $\mathrm{D}$.

The presence of high EC, TSS, TDS, BOD, and COD indicates that the river is contaminated by the high amount of organic and inorganic matter in the river (Anawar and Chowdhury, 2020). This might have resulted from the effluent from small and large-scale factories and toilets. The effluents from garages might also be responsible for the presence of a high amount of organic matter in the river. The high amount of BOD and COD are also responsible for the reduction of DO in the river (Bhateria and Jain, 2016; Jana and Sengupta, 1989).

Since Shankela River is one of the contributory rivers to Akaki River, the contamination of this river affects the quality of Akaki River. According to Mekonnen et al. (2020), Akaki River is the most contaminated river in Ethiopia. Therefore, to increase the quality of the biggest river in the city, which is Akaki River, the contributory rivers should be kept protected from any kind of pollution.

\section{CONCLUSIONS}

The main reasons for the poor liquid waste handling practices of Addis Ketema are the discharge of untreated effluents from small and large-scale factories, the migration of people from different parts of the country, and the poor solid waste handling practice of Merkato and Autobis Tera. The poor liquid waste handling practice of garages, residents, and condominium houses also plays a significant role in the poor 
liquid waste handling practice of Addis Ketema. Out of 81 garage employees, 57 of them have a perception about the health and environmental impact that comes due to the poor handling practice of garage effluent and the rest 43 do not have a perception about this. Among the 10 zones of Addis Ketema, zone 3 is the most polluted zone in the sub-city. Relatively, residents in zone 3 have the lowest number of people that have a perception about the health impact due to environmental pollution and have the lowest number of people that discharge their wastewater appropriately. Moreover, the highest number of people that have been affected by water-borne diseases, the highest number of people that dump their solid waste improperly, and the highest number of people that use bottled water are found in zone 3. Shankela River, which is one of the Contributor River of Akaki River, is also being affected by the poor wastewater collection and handling practice of the subcity. Developing sanitary infrastructures, Awareness creation, enforcing environmental laws are some methods that can be employed to solve the poor wastewater collection and handling practice of Addis Ketema. Handling liquid wastes appropriately is a key factor in improving the quality of life in developing country including Ethiopia. Therefore, it is suggested that researches needs to be conducted on liquid, as well as solid waste handling practice of different cities of the country, to investigate the status of sanitation services and practices for improvement.

Author contributions: All co-authors have involved in all stages of this study while preparing the final version. They all agree with the results and conclusions.

Funding: No external funding is received for this article.

Declaration of interest: The authors declare that they have no competing interests.

Ethics approval and consent to participate: Not applicable. Availability of data and materials: All data generated or analyzed during this study are available for sharing when appropriate request is directed to corresponding author.

\section{REFERENCES}

Abebaw, A. (2017). Monitoring the urban growth of Debre Markos Town (1984-2012), Ethiopia: Using satellite images and GPS. Journal of Geography and Regional Planning, 10(4), 69-76. https://doi.org/10.5897/JGRP2016.0533

Admassu, M., Wubshet, M. and Tilaye, T. (2004). Sanitary survey in Gondar town. Ethiopian Journal of Health Development, 17(3), 215-219. https://doi.org/10.4314/ ejhd.v18i1.9864

Alemayehu, T. A., Weldetinsae, A., Dinssa, D. A., Derra, F. A. et al. (2020). Sanitary condition and its microbiological quality of improved water sources in the southern region of Ethiopia. Environmental Monitoring and Assessment, 192(5), 319. https://doi.org/10.1007/s10661-020-08297-z

Amare, E., Kebede, F., Kloos, H. and Mulat, W. (2017). Wastewater confronting realities for sustainable livelihood in developing countries: Case study Mekelle University, Ethiopia. Water Conservation Science and Engineering, 2, 2130. https://doi.org/10.1007/s41101-017-0021-7
Amin, M. T., Alazba, A. A. and Manzoor, U. (2014). A review of removal of pollutants from water/wastewater using different types of nanomaterials. Advances in Materials Science and Engineering, 2014, Article ID 825910. https://doi.org/10.1155/2014/825910

Amoatey, P. and Bani, R. (2011). Wastewater management. In F. Sebastian and G. Einschlag (Eds.), Waste water Evaluation and management (pp. 379-398). INTECH Open Access Publisher. https://doi.org/10.5772/16158

Anawar, H. M. and Chowdhury, R. (2020). Remediation of polluted river water by biological, chemical, ecological and engineering processes. Sustainability, 12(17), 7017. https://doi.org/10.3390/su12177017

Attia, A. A., Khedr, S. A. and Elkholy, S. (2010). Adsorption of chromium ion (VI) by acid activated carbon. Brazilian Journal of Chemical Engineering, 27(1), 183-193. https://doi.org/10.1590/S0104-66322010000100016

Bazrafshan, E., Mohammadi, L., Ansari-Moghaddam, A. and Mahvi, A. H. (2015). Heavy metals removal from aqueous environments by electrocoagulation process- a systematic review. Journal of Environmental Health Science and Engineering, 13, 74. https://doi.org/10.1186/s40201-0150233-8

Berhe, B. A. (2020). Evaluation of groundwater and surface water quality suitability for drinking and agricultural purposes in Kombolcha town area, eastern Amhara region, Ethiopia. Applied Water Science, 10, 127. https://doi.org/10.1007/s13201-020-01210-6

Beyene, A., Hailu, T., Faris, K. and Kloos, H. (2015). Current state and trends of access to sanitation in Ethiopia and the need to revise indicators to monitor progress in the Post2015 era. BMC Public Health, 15, 451. https://doi.org/10.1186/s12889-015-1804-4

Bhateria, R. and Jain, D. (2016). Water quality assessment of lake water: A review. Sustainable Water Resources Management, 2, 161-173. https://doi.org/10.1007/s40899015-0014-7

Biefang, P. K., Defelice, S. V., Laws, E. A., Brand, L. E. et al. (2011). Prominent human health impacts from several marine microbes: History, ecology, and public health implications. International Journal of Microbiology, 2011, 152815. https://doi.org/10.1155/2011/152815

Bosch, C., Hommann, K., Rubio, G. M., Sadoff, C. W. et al. (2001). Water, sanitation and poverty. Draft chapter. Washington DC: World Bank.

Busvine, J. R. (1993). Disease transmission by insects: Its dscovery and 90 years of effort to prevent it. Springer Berlin Heidelberg.

Chalchisa, D., Megersa, M. and Beyene, A. (2018). Assessment of the quality of drinking water in storage tanks and its implication on the safety of urban water supply in developing countries. Environmental Systems Research, 6, 12. https://doi.org/10.1186/s40068-017-0089-2

CSA. (2012). 2007 Population and housing census of Ethiopia: Administrative report. Addis Ababa. Available at: https://www.ethiopianreview.com/pdf/001/Cen2007_firstd $\operatorname{raft}(1) . p d f$ 
Deeba, F., Abbas, N., Butt, M. T. and Irfan, M. (2019). Ground water quality of selected areas of Punjab and Sind Provinces, Pakistan: Chemical and microbiological aspects. Chemistry International, 5(4), 241-246. https://doi.org/ 10.2139/ssrn.3407494

Dorgham, M. M. (2014). Effects of Eutrophication. In: A. A. Ansari and S. S. Gill (Eds.) Eutrophication: Causes, consequences and control (Volume 2, pp. 29-44). Springer. https://doi.org/10.1007/978-94-007-7814-6_3

El-Gawad, H. S. A. (2014). Oil and grease removal from industrial wastewater using new utility approach. Advances in Environmental Chemistry, 2014. https://doi.org/10.1155/ 2014/916878

Exum, N. G., Kibira, S. P., Ssenyonga, R., Nobili, J. et al. (2019). The prevalence of schistosomiasis in Uganda: A nationally representative population estimate to inform control programs and water and sanitation interventions. PLoS Neglected Tropical Diseases, 13, e0007617. https://doi.org/ 10.1371/journal.pntd.0007617

Fayiga, A. O., Ipinmoroti, M. O. and Chirenje, T. (2018). Environmental pollution in Africa. Environment, Development and Sustainability, 20, 41-73. https://doi.org/ 10.1007/s10668-016-9894-4

Gbadegesin, O. A. and Akintola, S. O. (2020). A legal approach to winning the 'Wash' war in Nigeria. European Journal of Environment and Public Health, 4(2), em0043. https://doi.org/10.29333/ejeph/8237

Goncharuk, V. V. (2013). Water as the earth's buffer and immune system. Journal of Chemistry, 2013, 472323. https://doi.org/10.1155/2013/472323

Haddis, A., De Geyter, A., Smets, I. and Van Der Bruggen, B. (2014). Wastewater management in Ethiopian higher learning institutions: functionality, sustainability and policy context. Journal of Environmental Planning and Management, 57, 369-383. https://doi.org/10.1080/ 09640568.2012.745396

Iqbal, M., Abbas, M., Nisar, J., Nazir, A. et al. (2019). Bioassays based on higher plants as excellent dosimeters for ecotoxicity monitoring: A review. Chemistry International, $5,1-80$.

Jaishankar, M., Tseten, T., Anbalaan, N., Mathew, B. B. et al. (2014). Toxicity, mechanism and health effects of some heavy metals. Interdisciplinary Toxicology, 7, 60. https://doi.org/10.2478/intox-2014-0009

Jana, B. and Sengupta, S. (1989). Responses of dissolved oxygen, biochemical and chemical oxygen demands of water to artificial aeration. International Journal of Environmental Studies, 33, 307-315. https://doi.org/ 10.1080/00207238908710507

Jensen, P. E., Hennessy, T. W. and Kallenborn, R. (2018). Water, sanitation, pollution, and health in the Arctic. Environmental Science and Pollution Research, 25, 3282732830. https://doi.org/10.1007/s11356-018-3388-x

Joshi, A. and Amadi, C. (2013). Impact of water, sanitation, and hygiene interventions on improving health outcomes among school children. Journal of Environmental and Public Health, 2013, 984626. https://doi.org/10.1155/2013/984626
Kayiwa, D., Mugambe, R. K., Mselle, J. S., Isunju, J. B. et al. (2020). Assessment of water, sanitation and hygiene service availability in healthcare facilities in the greater Kampala metropolitan area, Uganda. BMC Public Health, 20. https://doi.org/10.1186/s12889-020-09895-9

Kijanga, M. M. (2019). Impact of liquid waste on environmental management in Ubungo Municipality: A case of Sinza War. [Master thesis, The Open University of Tanzania].

Li, H., Xia, Q., Wen, S., Wang, L. et al. (2019). Identifying factors affecting the sustainability of water environment treatment public-private partnership projects. Advances in Cvil Engineering, 2019, Article ID 7907234. https://doi.org/10.1155/2019/7907234

Liyanage, C. P. and Yamada, K. (2017). Impact of population growth on the water quality of natural water bodies. Sustainability, 9, 1405. https://doi.org/10.3390/su9081405

Loucks, D. P. and Van Beek, E. (2017). Water resources planning and management: An overview. Water Resource Systems Planning and Management, 1-49. https://doi.org/10.1007/978-3-319-44234-1_1

Majolagbe, A. O., Adeyi, A. A. and Osibanjo, O. (2016). Vulnerability assessment of groundwater pollution in the vicinity of an active dumpsite (Olusosun), Lagos, Nigeria. Chemistry International, 2(4), 232-241.

Majolagbe, A. O., Adeyi, A. A., Osibanjo, O., Adams, A. O. et al. (2017). Pollution vulnerability and health risk assessment of groundwater around an engineering Landfill in Lagos, Nigeria. Chemistry International, 3(1), 58-68.

Manderso, T. M. (2018). Overview of existing wastewater management system in case of Debre Markos Town, Ethiopia. Engineering Mathematics, 10(9), 23-35.

McFarland, A. R., Larsen, L., Yeshitella, K., Engida, A. N. et al. (2019). Guide for using green infrastructure in urban environments for stormwater management. Environmental Science: Water Research and Technology, 5(4), 643-659. https://doi.org/10.1039/C8EW00498F

Mekonnen, E. T., Temesgen, S. A. and Zhenbin, W. (2020). An overview of water pollution status in Ethiopia with a particular emphasis on Akaki River: A review. Ethiopian Journal of Public Health and Nutrition, 3, 120-128.

Mekonnen, F. H. (2012). Liquid waste management: The case of Bahir Dar, Ethiopia. Ethiopian Journal of Health Development, 26(1), 49-53.

Mukama, T., Ndejjo, R., Halage, A. A., Kasasa, S. et al. (2018). Drinking water supply, sanitation, and hygiene promotion interventions in two slum communities in Central Uganda. Journal of Environmental and Public Health, 2018, Article ID 3710120. https://doi.org/10.1155/2018/3710120

Mukama, T., Ndejjo, R., Musoke, D., Musinguzi, G. et al. (2016). Practices, concerns, and willingness to participate in solid waste management in two urban slums in Central Uganda. Journal of Environmental and Public Health, 2016, Article ID 6830163. https://doi.org/10.1155/2016/6830163

Nalwanga, E. and Ssempebwa, J. C. (2011). Knowledge and practices of in-home pesticide use: A community survey in Uganda. Journal of Environmental and Public Health, 2011, Article ID 230894. https://doi.org/10.1155/2011/230894 
Noreen, M., Shahid, M., Iqbal, M. and Nisar, J. (2017). Measurement of cytotoxicity and heavy metal load in drains water receiving textile effluents and drinking water in vicinity of drains. Measurement, 109, 88-99. https://doi.org/10.1016/j.measurement.2017.05.030

Oladoja, N. A. (2017). Appropriate technology for domestic wastewater management in under-resourced regions of the world. Applied Water Science, 7, 3391-3406. https://doi.org/10.1007/s13201-016-0495-z

Palaniappan, M., Gleick, P. H., Allen, L., Cohen, M. J. et al. (2010). Clearing the waters: a focus on water quality solutions. Pacific Institute. Available at: https://wedocs.unep.org/handle/20.500.11822/7906

Parween, M. and Ramanathan, A. L. (2019). Wastewater management to environmental materials management. In C.M. Hussain (Ed.) Handbook of environmental materials management (pp. 2745-2768). Springer. https://doi.org/ 10.1007/978-3-319-73645-7_72

Pirastu, R., Comba, P., Iavarone, I., Zona, A. et al. (2013). Environment and health in contaminated sites: The case of Taranto, Italy. Journal of Environmental and Public Health, 2013, Article ID 753719. https://doi.org/10.1155/2013/ 753719

Rice, E. W., Baird, R. B., Eaton, A. D. and Clesceri, L. S. (2012). Standard methods for the examination of water and wastewater.Availableat:https://www.standardmethods.org

Shrestha, N. R. (1988). Human relations and primary health care delivery in rural Nepal: The case of Deurali. The Professional Geographer, 40, 202-214. https://doi.org/ 10.1111/j.0033-0124.1988.00202.x
Slovin, E. (1960). Slovin's formula sampling techniques. Available at: https://sciencing.com/slovins-formulasampling-techniques-5475547.html

Tarekegn, M. M. and Truye, A. (2018). Causes and impacts of shankila river water pollution in Addis Ababa, Ethiopia. Environmental Risk Assessment and Remediation, 2(4), 2130.

Ukpaka, C. P. and Ukpaka, C. 2016. Characteristics of groundwater in Port-Harcourt local government area. Chemistry International, 2, 136-144.

van Dijk, M. P., Etajak, S., Mwalwega, B., Ssempebwa, J. (2013). Financing of sanitation services in the slums of Dar es Salaam and Kampala. Habitat International, 43, 206-213. https://doi.org/10.1016/j.habitatint.2014.02.003

Van Rooijen, D. J. and Taddesse, G. (2009). Urban sanitation and wastewater treatment in Addis Ababa in the Awash Basin, Ethiopia. In 34th WEDC International Conference.

Williams, D. R. (2004). Metals, health and the environmentemergence of correlations between speciation and effects. Bioinorganic Chemistry and Applications, 2, 317-330. https://doi.org/10.1155/S1565363304000196

Wu, X., Cobbina, S. J., Mao, G., Xu, H. et al. (2016). A review of toxicity and mechanisms of individual and mixtures of heavy metals in the environment. Environmental Science and Pollution Research, 23, 8244-8259. https://doi.org/ 10.1007/s11356-016-6333-X 